\title{
PENGARUH IMBAL JASA DAN BEBAN KERJA TERHADAP PRESTASI KERJA KARYAWAN PT AGAPE PRATAMA INDONESIA
}

\author{
Oleh:
}

Novianti

Karyawan PT. Agape Pratama Indonesia Palembang

\begin{abstract}
Research is a scientific study that aims to determine the effect of service rewards and workload on employee performance of PT Agape Pratama Indonesia. The number of samples used were 26 respondents. Through the questionnaires the data were collected and analyzed using descriptive statistics and parametric inferential statistics.

Descriptively the three research variables showed a good tendency. Inferentially parametric, multiple linear regression results show simultaneously significant influence of variable yield and workload to employee performance variable. However, the partial two variables did not show any significant effect on employee performance variable.
\end{abstract}

Keywords: Return on Services, Workload, Employee Performance

\begin{abstract}
ABSTRAK
Penelitian merupakan telaah ilmiah yang bertujuan untuk mengetahui pengaruh imbal jasa dan beban kerja terhadap prestasi kerja karyawan PT Agape Pratama Indonesia. Jumlah sampel yang digunakan sebanyak 26 responden. Melalui kuisioner data-data dikumpulkan dan dianalisis menggunakan statistik deskriptif dan statistik inferensial parametrik.

Secara deskriptif ketiga variabel penelitian menunjukkan kecenderungan yang baik. Secara inferensial parametris, hasil regresi linear berganda menunjukkan secara simultan adanya pengaruh signifikan variabel imbal jasa dan beban kerja terhadap variabel prestasi kerja karyawan. Akan tetapi secara parsial kedua variabel tidak menunjukkan adanya pengaruh yang signifikan terhadap variabel prestasi kerja karyawan.
\end{abstract}

Kata kunci: Imbal Jasa, Beban Kerja, Prestasi Kerja Karyawan

\section{PENDAHULUAN}

\subsection{Latar Belakang Masalah}

Manajemen sebuah perusahaan atau organisasi senantiasa dituntut mempertahankan dan mengembangkan produktifitas bagi karyawannya sehingga mampu 
memberikan kontribusi maksimal dan dapat mempertahankan eksistensi keberlangsungan dan pencapaian tujuan perusahaan atau organisasi. Keberhasilan pencapaian tujuan perusahaan tentunya tidak hanya ditentukan oleh besarnya dana yang dimiliki, teknologi yang digunakan, ataupun sarana dan prasarana yang dimiliki perusahaan, akan tetapi ada hal yang paling menentukan dalam mengorganisir setiap kegiatan usaha perusahaan yaitu faktor sumber daya manusia. Faktor inilah yang menggerakkan seluruh unsur yang dimiliki perusahaan dalam rangka proses pencapaian tujuan perusahaan.

Sumber daya manusia yang berkualitas menjadi harapan setiap perusahaan dalam mencapai tujuan-tujuan perusahaan. Kualitas sumber daya manusia perusahaan (karyawan) ditandai dengan keberhasilan kerja karyawan dalam mencapai hasil kerja yang baik dan terukur dalam mewujudkan harapan serta tujuan perusahaan. Mangkunegara (2004:67) menyatakan bahwa keberhasilan kerja karyawan sebagai bentuk prestasi kerja karyawan yaitu hasil kerja secara kualitas dan kuantitas yang dicapai oleh seorang pegawai (karyawan) dalam melaksanakan tugasnya sesuai dengan tanggung jawab yang diberikan kepadanya. Sedangkan Hasibuan (2004:94) menegaskan bahwa prestasi kerja adalah suatu hasil kerja yang dicapai seseorang dalam melaksanakan tugas-tugas yang dibebankan kepadanya yang didasarkan atas kecakapan, pengalaman, dan kesungguhan serta waktu. Dengan demikian dapat dinyatakan bahwa prestasi kerja merupakan capaian hasil kerja oleh karyawan yang didasarkan pada standar kerja yang ditetapkan oleh perusahaan dan dilakukan dengan penuh tanggung jawab.

Akan tetapi hasil studi pendahuluan yang penulis lakukan dalam bulan Desember 2017 mengungkapkan bahwa PT Agape Pratama Indonesia masih mengalami suatu masalah atau hambatan. Hal ini ditunjukkan dengan adanya indikasi prestasi kerja yang menurun yaitu sering terjadi penundaan pekerjaan sehingga banyak pekerjaan yang tidak selesai tepat pada waktunya. Bersamaan dengan adanya penurunan prestasi kerja karyawan PT Agape Pratama Indonesia tersebut, indikasi awal dari temuan studi pendahuluan ini juga mengungkapkan bahwa faktor organisasional yaitu faktor imbal jasa (gaji, bonus) dan beban kerja menjadi persoalan yang banyak dikeluhkan oleh karyawan.

Atas dasar temuan indikasi awal tersebut penulis bermaksud melakukan penelitian lebih lanjut, apakah imbal jasa dan beban kerja telah mempengaruhi turunnya prestasi kerja karyawan PT Agape Pratama Indonesia? Sehingga memberikan judul penelitian ini adalah: "Pengaruh Imbal jasa dan Beban Kerja terhadap Prestasi Kerja Karyawan PT Agape Pratama Indonesia".

\subsection{Rumusan Masalah}

Berdasarkan latar belakang masalah yang telah penulis uraikan di atas, maka rumusan masalah penelitian ini adalah:

Bagaimana pengaruh imbal jasa dan beban kerja terhadap prestasi kerja karyawan PT Agape Pratama Indonesia baik secara parsial maupun simultan?

\subsection{Tujuan Penelitian}


Penelitian ini berusaha menjawab permasalahan penelitian seperti tersebut di atas dengan tujuan dapat mengungkap dan mengetahui:

Bagaimana pengaruh imbal jasa dan beban kerja terhadap prestasi kerja karyawan PT Agape Pratama Indonesia baik secara parsial maupun simultan.

\subsection{Manfaat Penelitian}

Dengan melakukan penelitian ini diharapkan akan bermanfaat, antara lain:

1. Secara teoritis; dapat menambah dan meningkatkan wawasan pengetahuan civitas akademika tentang keberadaan imbal jasa dan beban kerja serta pengaruhnya terhadap prestasi kerja karyawan, serta sebagai referensi bagi penelitian selanjutnya

2. Secara praktis; bagi manajemen dan karyawan PT Agape Pratama Indonesia dapat menjadi masukkan tentang pentingnya imbal jasa dan beban kerja yang optimal bagi peningkatan prestasi kerja karyawan.

\subsection{Kerangka Pemikiran Dan Hipotesis}

Imbal jasa atau kompensasi merupakan fungsi manajemen sumberdaya manusia yang berhubungan dengan segala bentuk pemberian imbalan kepada pegawai sebagai balasan atas pelaksanaan tugas yang dilakukan oleh pegawai tersebut (Gibson dan Ivancevich, 2008:124). Dalam hubungan itu, Mathis dan Jackson (2006 :116-278) mengemukakan suatu sistem imbal jasa total meliputi imbal jasa finansial dan non finansial. Lebih lanjut dijabarkan bahwa imbal jasa finansial terdiri dari imbal jasa langsung dan imbal jasa tidak langsung. Imbal jasa langsung terdiri dari gaji pokok, pembayaran berdasarkan kinerja (seperti bagian saham, bonus, insentif) dan pembayaran berdasarkan keterampilan.

\section{Penelitian Terdahulu}

1. Jean Rosalina Asthenu (2014) dari hasil penelitiannya yang berjudul "Pengaruh Motivasi dan Kompensasi terhadap Prestasi Kerja Karyawan PT. Duta Hari Murthi (DHM) Konsultan", menyimpulkan bahwa kompensasi (imbal jasa) mempunyai pengaruh yang signifikan dan positif terhadap prestasi kerja karyawan PT DHM.

2. Lukiyana dan Firman Davi Firdaus (2017) dalam penelitiannya yang berjudul "Pengaruh Beban Kerja dan Lingkungan Kerja terhadap Prestasi Kerja Karyawan Dengan Kepuasan Kerja Sebagai Variabel Intervening Di Bagian Gudang pada PT. Sarijasa Transutama Jakarta", menyimpulkan bahwa beban kerja berpengaruh signifikan dan positif terhadap prestasi kerja karyawan PT STJ.

Berdasarkan kerangka pemikiran dan hasil penelitian terdahulu tersebut di atas, paradigma penelitian ini dapat digambarkan sebagai berikut.

Gambar 2.1

Paradigma Penelitian 


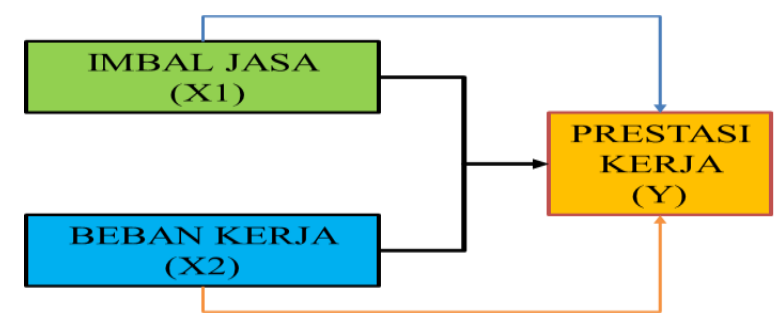

\subsection{Hipotesis Penelitian}

Berdasarkan rumusan masalah dan kerangka pemikiran serta paradigma penelitian tersebut di atas, diduga:

1. $\mathrm{H}_{0}: \mu=0$; Secara parsial (individual) tidak ada pengaruh yang signifikan imbal jasa terhadap prestasi kerja karyawan PT Agape Pratama Indonesia.

$\mathrm{H}_{1}: \mu \neq 0$; Secara parsial (individual) ada pengaruh yang signifikan imbal jasa terhadap prestasi kerja karyawan PT Agape Pratama Indonesia.

2. $\mathrm{H}_{0}: \mu=0$; Secara parsial (individual) tidak ada pengaruh yang signifikan beban kerja terhadap prestasi kerja karyawan PT Agape Pratama Indonesia.

$\mathrm{H}_{1}: \mu \neq 0$; Secara parsial (individual) ada pengaruh yang signifikan beban kerja terhadap prestasi kerja karyawan PT Agape Pratama Indonesia.

3. $\mathrm{H}_{0}: \mu=0$; Secara simultas (bersama-sama) tidak ada pengaruh yang signifikan imbal jasa dan beban kerja terhadap prestasi kerja karyawan PT Agape Pratama Indonesia. $\mathrm{H}_{1}: \mu=0$; Secara simultas (bersama-sama) ada pengaruh yang signifikan imbal jasa dan beban kerja terhadap prestasi kerja karyawan PT Agape Pratama Indonesia.

\section{LANDASAN TEORI}

\subsection{Imbal jasa}

\subsubsection{Pengertian Imbal jasa}

Pada umumnya setiap karyawan yang bekerja pada perusahaan menuntut imbal jasa atau kompensasi sebagai balas jasa atas pekerjaan yang telah dilakukan dalam periode tertentu. Berkenaan dengan hal tersebut beberapa ahli memberikan pengertian imbal jasa atau kompensasi sebagai berikut:

Gibson dan Ivancevich (2008:124) mengemukakan bahwa imbal jasa atau kompensasi merupakan fungsi manajemen sumberdaya manusia yang berhubungan dengan segala bentuk pemberian imbalan kepada pegawai sebagai balasan atas pelaksanaan tugas yang dilakukan oleh pegawai tersebut.

\subsubsection{Sistim Imbal jasa}

Mathis dan Jackson (2006 :116-278) mengemukakan suatu sistim imbal jasa atau kompensasi total meliputi imbal jasa finansial dan non finansial. Lebih lanjut dijabarkan bahwa sistim imbal jasa sebagai berikut:

1. Imbal jasa finansial terdiri dari imbal jasa langsung dan kompensasi tidak langsung. imbal jasa langsung terdiri dari gaji pokok, pembayaran berdasarkan kinerja (seperti bagian saham, bonus, insentif) dan pembayaran berdasarkan keterampilan. 
Sedangkan imbal jasa tidak langsung terdiri dari pelindungan umum (seperti jaminan sosial, pengangguran dan cacat), cuti kerja, sakit, liburan dan hari merah; dan tunjangan siklus hidup (seperti bantuan hukum, perawatan anak, dan biaya pindah.

2. Imbal jasa non finansial terdiri dari imbal jasa karier dan imbal jasa sosial. Imbal jasa karier terdiri dari rasa aman, kesempatan dan pengembangan diri, kesempatan kenaikan penghasilan dan fleksibilitas karier. Sedangkan imbal jasa sosial terdiri dari simbol status, pujian, pengakuan, kenyamanan tugas dan persahabatan.

Selain itu, menurut Hasibuan (2013:124), sistem pemberian imbal jasa yang umum diterapkan antara lain :

\subsubsection{Sistim Imbal jasa}

Mathis dan Jackson (2006 :116-278) mengemukakan suatu sistim imbal jasa atau kompensasi total meliputi imbal jasa finansial dan non finansial. Lebih lanjut dijabarkan bahwa sistim imbal jasa sebagai berikut:

3. Imbal jasa finansial terdiri dari imbal jasa langsung dan kompensasi tidak langsung. imbal jasa langsung terdiri dari gaji pokok, pembayaran berdasarkan kinerja (seperti bagian saham, bonus, insentif) dan pembayaran berdasarkan keterampilan. Sedangkan imbal jasa tidak langsung terdiri dari pelindungan umum (seperti jaminan sosial, pengangguran dan cacat), cuti kerja, sakit, liburan dan hari merah; dan tunjangan siklus hidup (seperti bantuan hukum, perawatan anak, dan biaya pindah.

4. Imbal jasa non finansial terdiri dari imbal jasa karier dan imbal jasa sosial. Imbal jasa karier terdiri dari rasa aman, kesempatan dan pengembangan diri, kesempatan kenaikan penghasilan dan fleksibilitas karier. Sedangkan imbal jasa sosial terdiri dari simbol status, pujian, pengakuan, kenyamanan tugas dan persahabatan.

\subsubsection{Komponen-Komponen Imbal jasa}

Menurut Flippo (dalam Handoko, 2001:56), imbal jasa dibagi menjadi dua bagian, yaitu:

1. Imbal jasa Langsung (Direct Compensation)

Imbal jasa langsung merupakan kompensasi yang diterima oleh karyawan yang mempunyai hubungan langsung dengan pekerjaan, yang biasanya diterima oleh karyawan dalam bentuk gaji, upah, intensif, dan/atau bonus. Lebih rinci hal tersebut dapat dijelaskan sebagai berikut:

a. Gaji, yaitu sejumlah uang yang diterima secara langsung setiap bulan/minggu untuk karyawan tetap sebagai imbalan atas pekerjaannya sedangkan bila terjadi naik/turunnya prestasi kerja, tidak mempengaruhi besar kecilnya gaji tetap. Besar kecilnya nilai gaji terjadi apabila terjadi kenaikan atau penurunan nilai gaji yang ditetapkan oleh perusahaan.

b. Upah, yaitu sejumlah uang yang diterima secara langsung setiap minggu/harian untuk pegawai tidak tetap atau biasa disebut dengan part-time sebagai imbalan yang berkaitan dengan pekerjaan borongan atau menghadapi event-even tertentu.

c. Insentif, yaitu sejumlah uang yang diterima secara langsung setiap bulan/minggu untuk karyawan tetap atau part-time sebagai imbalan kasus perkasus yang dikerjakan berdasarkan keterampilan kinerjanya. Atau tambahan 
balas jasa yang diberikan kepada karyawan tertentu yang prestasinya diatas prestasi standar.

d. Bonus, yaitu sejumlah uang yang diterima secara langsung sebagai imbalan atas prestasi kerja yang tinggi untuk jangka waktu tertentu, dan jika prestasinya sedang menurun, maka bonusnya tidak akan diberikan.

2. Imbal jasa Tidak Langsung (Indirect Compensation)

Imbal jasa tidak langsung merupakan kompensasi yang diterima oleh karyawan yang tidak mempunyai hubungan langsung dengan pekerjaan, tetapi lebih menekankan kepada pembentukan kondisi kerja yang baik untuk menyelesaikan pekerjaannya. Imbal jasa ini berkenaan dengan:

\section{Beban Kerja}

\subsubsection{Pengertian Beban Kerja}

Beberapa pengertian beban kerja telah dikemukan oleh para ahli, diantaranya adalah sebagai berikut:

1. Gibson dan Ivancevich (2008:163) yang mengemukakan bahwa beban kerja merupakan tekanan sebagai tanggapan yang tidak dapat menyesuaikan diri, yang dipengaruhi oleh perbedaan individual atau proses psikologis, yakni suatu konsekuensi dari setiap tindakan ekstern (lingkungan, situasi, peristiwa yang terlalu banyak mengadakan tuntutan psikologi atau fisik) terhadap seseorang.

2. Munandar (2001:380), menyatakan bahwa beban kerja adalah keadaan dimana pekerja dihadapkan pada tugas yang harus diselesaikan pada waktu tertentu.

3. Danang Sunyoto (2012:64), beban kerja adalah yang terlalu banyak dapat menyebabkan ketegangan dalam diri seseorang sehingga menimbulkan stress. Hal ini bisa disebabkan oleh tingkat keahlian yang dituntut terlalu tinggi, kecepatan kerja mungkin terlalu tinggi, volume kerja mungkin terlalu banyak dan sebagainya.

\subsubsection{Aspek dan Dimensi Beban Kerja}

Dua aspek penting yang menjadi beban kerja, menurut Munandar (2001:381), adalah:

Beban kerja sebagai tuntutan Fisik.

Kondisi kerja tertentu dapat menghasilkan prestasi kerja yang optimal di samping dampaknya terhadap kinerja pegawai, kondisi fisik berdampak pula terhadap kesehatan mental seorang tenaga kerja. Kondisi fisik pekerja mempunyai pengaruh terhadap kondisi fatal dan psikologi seseorang. Dalam hal ini bahwa kondisi kesehatan pegawai harus tetap dalam keadaan sehat saat melakukan pekerjaan, selain istirahat yang cukup juga dengan dukungan sarana tempat kerja yang nyaman dan memadai.

\subsubsection{Faktor yang Mempengaruhi Beban Kerja}

Berat-ringannya beban kerja dapat dipengaruhi oleh berbagai faktor. Menurut Soleman (2011:85), faktor-faktor yang memengaruhi beban kerja adalah sebagai berikut:

1. Faktor eksternal

Faktor eksternal adalah beban kerja yang berasal dari luar tubuh pekerja, antara lain yaitu: 
a. Tugas (Task). Meliputi tugas bersifat seperti, stasiun kerja, tata ruang tempat kerja, kondisi ruang kerja, kondisi lingkungan kerja, sikap kerja, cara angkut, beban yang diangkat. Sedangkan tugas yang bersifat mental meliputi, tanggung jawab, kompleksitas pekerjaan, emosi pekerjaan dan sebagainya.

b. Organisasi kerja. Meliputi lamanya waktu kerja, waktu istirahat, shift kerja, sistem kerja dan sebagainya.

c. Lingkungan kerja. Lingkungan kerja dapat memberikan beban tambahan yang meliputi, lingkungan kerja fisik, lingkungan kerja biologis dan lingkungan kerja psikologis.

2. Faktor internal

Faktor internal adalah faktor yang berasal dari dalam tubuh akibat dari reaksi beban kerja eksternal yang berpotensi sebagai stresor, meliputi faktor somatis (jenis kelamin, umur, ukuran tubuh, status gizi, kondisi kesehatan, dan sebagainya), dan faktor psikis (motivasi, persepsi, kepercayaan, keinginan, kepuasan, dan sebagainya).

\subsection{Prestasi Kerja}

Terwujudnya hasil kerja karyawan yang berkualitas dan secara kuantitas terpenuhinya target-target yang telah ditetapkan perusahaan menjadi tolok ukur tercapainya prestasi kerja karyawan. Prestasi kerja menurut para ahli dapat didefinisikan sebagi berikut, antara lain:

1. Mangkunegara (2004:67) menyatakan bahwa keberhasilan kerja karyawan merupakan bentuk prestasi kerja karyawan yaitu hasil kerja secara kualitas dan kuantitas yang dicapai oleh seorang karyawan dalam melaksanakan tugasnya sesuai dengan tanggung jawab yang diberikan kepadanya.

2. Nindyati (2003:22) menjelaskan bahwa pemahaman tentang prestasi kerja tidak bisa dilepaskan dari pemahaman yang bersifat multidimensional. Kemauan dan kemampuan yang dimiliki seseorang dalam melakukan pekerjaan dapat terlihat dari prestasi kerjanya, dalam usaha penerapan konsep, gagasan, ide dengan efektif dan efisien sehingga tercapai tujuan yang ditetapkan oleh perusahaan..

\subsubsection{Penilaian (Pengukuran) Prestasi Kerja}

Ukuran terakhir keberhasilan dari suatu departemen personalia adalah prestasi kerja. Karena baik departemen itu sendiri maupun karyawan memerlukan umpan balik atas upayanya masing-masing, maka prestasi kerja dari setiap karyawan perlu dinilai. Oleh karena itu Penilaian prestasi kerja adalah proses melalui mana organisasi-organisasi mengevaluasi atau menilai prestasi kerja Menurut Heidrahman dan Suad Husnan (1990:126)

\subsubsection{Kegunaan Penilaian Prestasi Kerja}

Hasil penilaian prestasi kerja dapat memperbaiki keputusan-keputusan personalia dan memberikan umpan balik kepada karyawan tentang pelaksanaan kerja mereka. Oleh karena itu kegunaan penilaian prestasi kerja dapat dirinci sebagai berikut: (T. Hani Handoko,1987:135-136)

\section{METODE PENELITIAN}




\subsection{Objek Penelitian}

Objek penelitian ini adalah karyawan PT. Agape Pratama Indonesia terletak di jalan Jenderal Bambang Utoyo Ruko 06 - Palembang. PT. Agape Pratama Indonesia adalah sebuah perusahaan handal dan terpercaya dalam bidang jasa dan pelayanan pengadaan barang.

\subsection{Desain Penelitian}

Penelitian ini didesain dalam suatu penelitian deskriptif dan asosiatif. Desain deskriptif digunakan untuk menjelaskan kondisi masing-masing variabel independen maupun dependennya, yaitu variabel imbal jasa, beban kerja dan variabel prestasi kerja karyawan. Sedangkan dalam bentuk asosiatif akan membuktikan hipotesis penelitian dengan menggunakan uji statistik parametrik.

\subsection{Operasional Variabel}

Penelitian ini terdiri dari dua jenis variabel, yaitu variabel independen dan variabel dependen. Variabel independen penelitian ini adalah variabel imbal jasa dan variabel beban kerja. Sedangkan variabel dependen peneltian ini adalah variabel prestasi kerja karyawan. Masing-masing variabel tersebut dapat dijelaskan, sebagai berikut:

1. Tabel 3.1

\section{Variabel Operasional Peneltian}

\begin{tabular}{|c|c|c|c|}
\hline Variabel & Konsep Variabel & Indikator & Skala \\
\hline $\begin{array}{l}\text { Imbal } \\
\text { jasa }\end{array}$ & $\begin{array}{l}\text { Sistem kompensasi total } \\
\text { yang meliputi } \\
\text { kompensasi finansial } \\
\text { dan non finansial } \\
\text { (Mathis dan Jackson, } \\
2006: 116 \text { ) }\end{array}$ & $\begin{array}{l}\text { - Imbal jasa finansial; } \\
\text { imbal jasa langsung dan } \\
\text { tidak langsung. } \\
\text { - Imbal jasa non finansial; } \\
\text { imbal jasa karier dan } \\
\text { sosial }\end{array}$ & $\begin{array}{l}\text { Ordinal } \\
\text { (Likert) }\end{array}$ \\
\hline $\begin{array}{l}\text { Beban } \\
\text { kerja }\end{array}$ & $\begin{array}{l}\text { Keadaan dimana pekerja } \\
\text { dihadapkan pada tugas } \\
\text { yang harus diselesaikan } \\
\text { pada waktu tertentu } \\
\text { (Munandar, 2001:380) }\end{array}$ & $\begin{array}{l}\text { Faktor ekternal; tugas } \\
\text { (task), organisasi kerja, } \\
\text { dan lingkungan kerja. } \\
\text { - Faktor internal; somatis } \\
\text { dan psikis. }\end{array}$ & $\begin{array}{l}\text { Ordinal } \\
\text { (Likert) }\end{array}$ \\
\hline $\begin{array}{l}\text { Prestasi } \\
\text { kerja }\end{array}$ & $\begin{array}{l}\text { Hasil kerja secara } \\
\text { kualitas dan kuantitas } \\
\text { yang dicapai oleh } \\
\text { seorang karyawan dalam } \\
\text { melaksanakan tugasnya } \\
\text { sesuai dengan tanggung } \\
\text { jawab yang diberikan } \\
\text { kepadanya } \\
\text { (Mangkunegara, }\end{array}$ & $\begin{array}{l}\text { - Kualitas kerja } \\
\text { - Kuantitas kerja } \\
\text { - Disiplin kerja } \\
\text { - Inisiatif } \\
\text { - Kerjasama } \\
\text { (Nasution, 2000:99) }\end{array}$ & $\begin{array}{l}\text { Ordinal } \\
\text { (Likert) }\end{array}$ \\
\hline
\end{tabular}




\begin{tabular}{|l|l|l|l|}
\hline $2004: 67)$ & & \\
\hline
\end{tabular}

\subsection{Metode Penarikan Sampel}

Populasi adalah wilayah generalisasi yang terdiri atas objek atau subyek yang mempunyai kualitas dan karakteristik tertentu yang ditetapkan oleh peneliti untuk dipelajari dan kemudian di tarik kesimpulannya, sedangkan sampel adalah bagian dari jumlah dan karakteristik yang dimiliki oleh populasi (Sugiyono, 2010:61-62). Populasi penelitian ini adalah keseluruhan karyawan PT. Agape Pratama Indonesia yang berjumlah 26 orang. Dan jumlah sampel penelitian adalah jumlah seluruh karyawan 26 orang tersebut, dengan kata lain pengambilan sampel dilakukan dengan menggunakan teknik sampling jenuh (saturation sampling).

\subsection{Prosedur Pengumpulan Data}

Pengumpulan data penelitian untuk semua variabel dilakukan dengan cara angket (kuisioner), yaitu memberikan daftar pertanyaan kepada responden (karyawan) dengan pilihan jawaban tertutup dan terstruktur. Pilihan jawaban menggunakan skala likert yang terdiri dari 5 (lima) pilihan jawaban,

\subsection{Teknik Analisis Data}

Mengacu pada permasalahan dan hipotesis penelitian tersebut di atas, maka teknik analisis data penelitian ini meliputi teknik analisis statistik deskriptif dan teknik analisis statistik inferensial parametrik. Teknik analisis statistik deskriptif digunakan untuk mendeskripsikan masing-masing variabel secara mandiri dalam bentuk tabel distribusi frekuensi dan skor persentasi kecenderungan jawaban responden.Sedangkan teknik analisis statistik inferensial parametris digunakan untuk menjawab permasalahan sekaligus membuktikan hipotesis penelitian dengan menggunakan analisis regresi linear berganda.

\subsubsection{Uji Validitas dan Reliabilitas Data Kuisioner}

Sebelum melakukan teknik analisis statistik deskriptif kualitatif dan teknik analisis statistik inferensial parametris, terlebih dahulu dilakukan uji validitas dan reliabiltas data kuisioner, sebagai berikut:

\subsubsection{Uji Validitas}

Uji Validitas digunakan untuk mengukur sah atau tidaknya suatu data kuesioner yaitu mampu mengungkapkan sesuatu yang akan diukur oleh kuesioner tersebut. Untuk mengukur validitas dapat dilakukan dengan cara mengkorelasikan skor setiap butir pertanyaan dengan skor totalnya. Untuk mengetahui skor masing-masing item pertanyaan valid atau tidak, maka ditetapkan kriteria statistik berdasarkan korelasi menurut Pearson Moment (Sudjana, 2005: 72), dengan rumus sebagai berikut:

\subsubsection{Uji Reliabilitas}

Uji reliabilitas adalah mengukur suatu data kuisioner yang dinyatakan reliabel atau handal jika jawaban seseorang terhadap pernyataan adalah konsisten atau stabil dari 
waktu ke waktu. Pengukuran reliabilitas tersebut dilakukan dengan menggunakan rumus alpha cronbach (Sudjana, 2005: 109), yaitu:

Jika $r_{11}$ pada tingkat signifikansi 5\%, lebih besar dari r-kritis atau 0,6 (Sekaran Teknik Analisis Statistik Deskriptif

Teknik analisis statistik deskriptif digunakan untuk memberikan gambaran data pada masing-masing variabel dalam bentuk distribusi frekuensi dan skor persentase kecenderungan jawaban responden atas pertanyaan dalam kusioner. Skor persentase untuk menyatakan kecenderungan jawaban responden tinggi, sedang dan rendah

\section{Teknik Analisis Statistik Inferensial Parametrik}

Teknik Analisis Statistik Inferensial Parametrik menggunakan teknik analisis statistik regresi linear berganda yang meliputi langkah-langkah analisis sebagai berikut:

Model regresi, yaitu:

$$
Y_{i}=\alpha+\beta_{1} X_{1}+\beta_{2} X_{2}+\varepsilon
$$

Dimana:

$\mathrm{Yi}=$ Variabel prestasi kerja karyawan ke-i

$\mathrm{X}_{1} \quad=$ Variabel imbal jasa karyawan

$\mathrm{X}_{2} \quad=$ Variabel beban kerja karyawan

$\alpha=$ Bilangan konstan regresi

$\beta \quad=$ Koefisien regresi ke 1,2

$\varepsilon \quad=$ Standar kesalahan

\section{PEMBAHASAN}

\section{Profil PT Agape Pratama Indonesia}

PT.Agape Pratama Indonesia merupakan perusahaan swasta yang bergerak dalam bidang jasa pelayanan sistem pengendalian terpadu dalam hal pencegahan dan pengendalian bahaya kebakaran, keselamatan kerja serta menciptakan lingkungan kerja yang aman.

PT.Agape Pratama Indonesia berdiri tanggal 26 Oktober 2001 di Palembang berdasarkan Akta Notaris Husnawati, SH No. 162 Tanggal 26 Okober 2001, dan Akta Perubahan No.08 Tanggal 06 Februari 2006.

\section{Analisis Data}

Data-data penelitian ini telah dikumpulkan, diidentifikasi, dan dianalisis dengan menggunakan program Microsoft Excel dan program SPSS v.23. Hasil analisis data diuraikan dalam dua bentuk analisis yaitu analisis statistik deskripsi dan analisis statistik parametrik.

\section{Analisis Statistik Deskriptif}

Analisis statistik deskriptif akan menggambarkan nilai-nilai statistik tendency central (ukuran pemusatan data) yaitu menggunakan ukuran modus untuk data berbentuk 
kategori (nominal maupun ordinal). Analisis ini meliputi analisis karakteristik responden dan analisis kecenderungan jawaban responden.

\section{Karakteristik Responden}

Penelitian ini menelaah 3 (tiga) jenis karakteristik responden, yaitu usia, jenis kelamin, pendidikan terakhir dan lama berkerja responden di PT Agape Pratama Indonesia. Masing-masing karakteristik tampak dalam tabel 4.1, tabel 4.2, tabel 4.3 dan tabel 4.4 di bawah ini.

Tabel 4.1

Distribusi Frekuensi Usia Responden

\begin{tabular}{|ll|r|r|r|r|}
\hline & Frequency & Percent & Valid Percent & $\begin{array}{c}\text { Cumulative } \\
\text { Percent }\end{array}$ \\
\hline Valid & 15 s/d 24 & 7 & 26,9 & 26,9 & 26,9 \\
& 25 s/d 34 & 16 & 61,5 & 61,5 & 88,5 \\
35 s/d 44 & 2 & 7,7 & 7,7 & 96,2 \\
34 s/d 54 & 1 & 3,8 & 3,8 & 100,0 \\
& 26 & 100,0 & 100,0 & \\
\hline
\end{tabular}

Tabel 4.2

Distribusi Frekuensi Jenis Kelamin Responden

\begin{tabular}{|ll|r|r|r|r|}
\hline & Frequency & Percent & Valid Percent & $\begin{array}{c}\text { Cumulative } \\
\text { Percent }\end{array}$ \\
\hline Valid & Perempuan & 10 & 38,5 & 38,5 & 38,5 \\
& Laki-laki & 16 & 61,5 & 61,5 & 100,0 \\
& Total & 26 & 100,0 & 100,0 & \\
\hline
\end{tabular}

Tabel 4.3

Distribusi Frekuensi Pendidikan Terakhir Responden

\begin{tabular}{|ll|r|r|r|r|}
\hline & Frequency & Percent & Valid Percent & $\begin{array}{c}\text { Cumulative } \\
\text { Percent }\end{array}$ \\
\hline Valid & SMAVSederajat & 9 & 34,6 & 34,6 & 34,6 \\
& 5 & 19,2 & 19,2 & 53,8 \\
& Diploma & 12 & 46,2 & 46,2 & 100,0 \\
Sarjana & 26 & 100,0 & 100,0 & \\
Total & & \\
\hline
\end{tabular}

Tabel 4.4

Distribusi Frekuensi Masa Bekerja Responden 


\begin{tabular}{|c|c|c|c|c|c|}
\hline & & Frequency & Percent & Valid Percent & $\begin{array}{c}\text { Cumulative } \\
\text { Percent }\end{array}$ \\
\hline \multirow[t]{4}{*}{ Valid } & $<6$ Tahun & 22 & 84,6 & 84,6 & 84,6 \\
\hline & $6 \mathrm{~s} / \mathrm{d} 10$ Tahun & 3 & 11,5 & 11,5 & 96,2 \\
\hline & > 10 Tahun & 1 & 3,8 & 3,8 & 100,0 \\
\hline & Total & 26 & 100,0 & 100,0 & \\
\hline
\end{tabular}

\section{Uji Validitas dan Reliabilitas Data}

Penelitian ini terdiri dari tiga variabel yaitu variabel imbal jasa, beban kerja dan variabel prestasi kerja karyawan. Dengan menggunakan kuisioner berskala likert

\section{Analisis Statistik Inferensial Parametrik}

Analisis statistik infernsial parametrik penelitian ini menggunakan analisis regresi linear berganda. Hasil analisis menggunakan program SPSS v.23 dapat diuraikan sebagai berikut.

\section{Model Regresi Linear Berganda}

Tabel 4.12

Koefisien Regresi Linear Berganda

Coefficients $^{\mathrm{a}}$

\begin{tabular}{|c|c|c|c|c|}
\hline \multirow{2}{*}{\multicolumn{2}{|c|}{ Model }} & \multicolumn{2}{|c|}{ Unstandardized Coefficients } & \multirow{2}{*}{$\begin{array}{c}\begin{array}{c}\text { Standardized } \\
\text { Coefficients }\end{array} \\
\text { Beta }\end{array}$} \\
\hline & & B & Std. Error & \\
\hline \multirow[t]{3}{*}{1} & (Constant) & 11,226 & 4,613 & \\
\hline & TS_Xij & ,403 & ,239 & ,349 \\
\hline & TS_Xbk & 270 & ,252 & 222 \\
\hline
\end{tabular}

a. Dependent Variable: TS_Ypk

Sumber: Output SPSS v.23

Tabel di atas menunjukkan angka konstanta dan koefisien regresi masing-masing sebesar 11,$226 ; 0,403 ; 0,270$ sehingga model regresi dapat dirumuskan yaitu:

$$
Y_{p k}=11,226+0,403 X_{i j}+0,270 X_{b k}
$$

Dengan demikian dapat dikatakan: 
a. Jika variabel imbal jasa $\left(\mathrm{X}_{\mathrm{ij}}\right)$ bernilai 1 , sementara variabel beban kerja $\left(\mathrm{X}_{\mathrm{bk}}\right)$ dianggap nol atau tetap, maka variabel prestasi kerja $\left(\mathrm{Y}_{\mathrm{pk}}\right)$ akan bertambah sebesar 0,403 atau 40,3\%.

b. Jika variabel beban kerja $\left(X_{\mathrm{bk}}\right)$ bernilai 1 , sementara variabel imbal jasa $\left(X_{\mathrm{ij}}\right)$ dianggap nol atau tetap, maka variabel prestasi kerja $\left(\mathrm{Y}_{\mathrm{pk}}\right)$ akan bertambah sebesar 0,270 atau $27 \%$.

c. Jika variabel imbal jasa $\left(\mathrm{X}_{\mathrm{ij}}\right)$ dan variabel beban kerja $\left(\mathrm{X}_{\mathrm{bk}}\right)$ dianggap nol atau tetap, maka variabel prestasi kerja $\left(\mathrm{Y}_{\mathrm{pk}}\right)$ akan tetap sebesar 11,226.

\section{Uji Asumsi Klasik}

Uji asumsi klasik bertujuan untuk membuktikan bahwa model regresi telah memenuhi asumsi-asumsi regresi linear berganda sehingga model regresi bersifat BLUE (Best Linear Unbias Estimator) atau suatu model regresi yang tidak bias sebagai alat prediksi. Dengan menggunakan program SPSS v.23,

\section{Coefficients ${ }^{a}$}

\begin{tabular}{|c|c|c|c|c|c|c|}
\hline \multirow[b]{2}{*}{ Mode } & & \multicolumn{2}{|c|}{ Unstandardized Coefficients } & $\begin{array}{c}\text { Standardized } \\
\text { Coefficients }\end{array}$ & \multirow[b]{2}{*}{$t$} & \multirow[b]{2}{*}{ Sig. } \\
\hline & & $B$ & Std. Error & Beta & & \\
\hline \multirow[t]{3}{*}{1} & (Constant) & $-1,932$ & 2,680 & &,- 721 &, 478 \\
\hline & TS_Xij &, 038 & 139 &, 063 &, 275 &, 785 \\
\hline & TS_Xbk & 164 &, 146 & .255 & 1,119 &, 275 \\
\hline
\end{tabular}

a. Dependent Variable:RES_2

\section{Koefisien Korelasi (R) dan Koefisien Determinasi (Adj. $\mathbf{R}^{\mathbf{2}}$ ) (Simultan)}

\begin{tabular}{|c|c|c|c|c|c|c|c|c|c|}
\hline \multicolumn{10}{|c|}{ Model Summary } \\
\hline \multirow[b]{2}{*}{ Model } & \multirow[b]{2}{*}{$\mathrm{R}$} & \multirow[b]{2}{*}{ R Square } & \multirow[b]{2}{*}{$\begin{array}{l}\text { Adjusted R } \\
\text { Square }\end{array}$} & \multirow[b]{2}{*}{$\begin{array}{l}\text { Std. Error of } \\
\text { the Estimate }\end{array}$} & \multicolumn{5}{|c|}{ Change Statistics } \\
\hline & & & & & $\begin{array}{c}\text { R Square } \\
\text { Change }\end{array}$ & $F$ Change & df1 & $d f 2$ & $\begin{array}{l}\text { Sig. } F \\
\text { Change }\end{array}$ \\
\hline 1 & $496^{\mathrm{a}}$ & 246 &, 181 & 1,79787 & 246 & 3,754 & 2 & 23 &, 039 \\
\hline
\end{tabular}

a. Predictors: (Constant), TS_Xbk, TS_Xij

b. Dependent Variable: TS_Ypk

\section{Uji F (Simultan)}

Untuk membuktikan hipotesis penelitian secara simultan, digunakan uji f dengan hasil hitung program SPSS tampak pada tabel 4.18 di

Tabel 4.18

Uji F 
ANOVA ${ }^{\text {a }}$

\begin{tabular}{|ll|r|r|r|r|r|}
\hline Model & & $\begin{array}{c}\text { Sum of } \\
\text { Squares }\end{array}$ & df & Mean Square & F & Sig. \\
\hline 1 & Regression & 24,271 & 2 & 12,136 & 3,754 &, $039^{\mathrm{b}}$ \\
& Residual & 74,344 & 23 & 3,232 & & \\
& Total & 98,615 & 25 & & & \\
\hline
\end{tabular}

a. Dependent Variable: TS_Ypk

b. Predictors: (Constant), TS_Xbk, TS_Xij

Hasil deskripsi data masing-masing variabel penelitian menunjukkan bahwa imbal jasa yang diterima karyawan PT Agape Pratama Indonesia memuaskan, beban kerja karyawan dan prestasi kerja tinggi. Dengan kata lain dengan beban kerja yang tinggi, imbal jasa yang memuaskan, karyawan dapat menunjukkan prestasinya dengan baik dalam menjalankan tugas dan kewajibannya baik secara individual maupun dalam tim kerja.

Dengan imbal jasa yang memuaskan diharapkan tujuan pemberian imbal jasa dapat terwujud dengan baik, seperti yang dikemukan oleh Hasibuan (2013:121) bahwa tujuan pemberian imbal jasa akan mewujudkan terjalinnya ikatan kerjasama formal antara majikan dengan karyawan dengan baik, kepuasan kerja dapat dirasakan karyawan, pengadaan karyawan yang qualifield untuk perusahaan akan lebih mudah, akan lebih mudah memotivasi bawahan, dan stabilitas karyawan akan lebih terjamin karena turnover relatif kecil.

\section{KESIMPULAN DAN SARAN}

\section{Kesimpulan}

Berdasarkan pada hasil analisis dan pembahasan yang telah dikemukakan di atas, dapat dirumuskan beberapa kesimpulan sebagai berikut:

1. Imbal jasa yang diterima karyawan PT Agape Pratama Indonesia selama ini telah memberikan kepuasan bagi karyawannya.

2. Karyawan PT Agape Pratama Indonesia selama ini mempunyai beban kerja yang tinggi.

3. Karyawan PT Agape Pratama Indonesia mempunyai prestasi kerja yang tinggi.

4. Secara simultan (bersama-sama/serentak) variabel imbal jasa dan variabel beban kerja mempunyai pengaruh yang signifikan terhadap prestasi kerja karyawan PT Agape Pratama Indonesia. Kedua variabel ini harus ada dan berlangsung bersamaan jika diharapkan memiliki dampak yang berarti terhadap kenaikan prestasi kerja karyawan.

5. Secara individual (parsial) variabel imbal jasa dan variabel beban kerja tidak mempunyai pengaruh yang signifikan terhadap prestasi kerja karyawan PT Agape Pratama Indonesia, hal ini disebabkan secara mandiri hubungan masing-masing variabel rendah dengan prestasi kerja karyawan.

\section{Saran-saran}


Sebagai saran-saran yang perlu disampaikan dalam hubungannya dengan hasilhasil penelitian ini adalah:

1. PT Agape Pratama Indonesia hendaklah tetap memacu peningkatan imbal jasa, menurunkan beban kerja karyawan secara proposional, dan terus memberikan motivasi terhadap peningkatan prestasi karyawannya, sehingga kondisi karyawan benar-benar dalam keadaan yang prima dalam bekerja dan mencapai tujuan-tujuan perusahaan.

2. Penelitian ini mengkaitkan dua variabel independen yaitu imbal jasa dan beban kerja dengan prestasi kerja karyawan. Banyak faktor yang dapat mempengaruhi naik turunnya prestasi kerja karyawan, seperti usia, pendidikan, dan lain-lain. Oleh akrena itu, penelitian lebih lanjut dengan menggunakan faktor-faktor lainnya tersebut tentu akan menghasilkan kesimpulan yang lebih komprehensif dan mendalam.

\section{DAFTAR PUSTAKA}

Asthenu, Jean Rosalina. 2015. Pengaruh Motivasi dan Kompensasi terhadap Prestasi Kerja Karyawan PT. Duta Hari Murthi (DHM) Konsultan. Jurnal POLI BISNIS, 7 (2). pp. 1-14. ISSN 1858-3717 November 2015. Diakses dari http://repo.polinpdg.ac.id/445/1/889-867-1-PB.pdf, pada tanggal 8 November 2017

Davis, Keith dan Newstrom, John W. 1985. Perilaku Dalam Organisasi. Jakarta: Erlangga

Donnelly, Gibson \& Ivancevich. 2008. Perilaku Struktur Proses. Erlangga, Jakarta.

Hasibuan, Malayu S.P. 2004. Manajemen Sumber Daya Manusia, Edisi Revisi. Bumi Aksara, Jakarta.

Handoko, T Hani.1997. Manajemen Personalia dan Sumber Daya Manusia, Edisi kedua. BPFE, UGM. Yogyakarta,

1996. Manajemen, Edisi Kedua, Penerbit BPFE, Yogyakarta, 1996

Heidjracman dan Suad Husnan. 1990. Personalia, BPFE, Yogyakarta

Lukiyana \& Firdaus, Firman Davi. 2017. Pengaruh Beban Kerja dan Lingkungan Kerja terhadap Prestasi Kerja Karyawan Dengan Kepuasan Kerja Sebagai Variabel Intervening Di Bagian Gudang pada PT. Sarijasa Transutama Jakarta. Jurnal BIJAK Vol. 14, No. 02, September 2017 ISSN 1411-0830. Majalah Ilmiah Institut STIAMI. Diakses dari http://www.stiami.ac.id/jurnal/download/219 pada tanggal 5 Februari 2018. 
Mangkunegara, Anwar Prabu. 2004. Manajemen Sumber Daya Manusia. PT. Remaja Rosda Karya, Bandung.

Mathis, R.L. \& J.H. Jackson. 2006. Human Resource Management: Manajemen Sumber Daya Manusia. Terjemahan Dian Angelia. Salemba Empat, Jakarta

Moekijat. 2004. Manajemen Tenaga Kerja dan Hubungan Kerja. Bandung: Pioner Jaya.

Munandar. 2001. Stress dan keselamatan Kerja, Psikologi Industri dan organisasi. Universitas Indonesia, Jakarta.

Nasution, Mulia, 2000. Manajemen Personalia Aplikasi Dalam Perusahaan. Djambatan, Jakarta.

O’Donnell dan Eggemeier. 1986. Workload Assessment Methodology. New York: Wiley.

Phalestie, Aloysia Alfra. (2007). Hubungan Trait Kepribadian dan Kemampuan Komunikasi Interpersonal dengan Prestasi Kerja Agen Asuransi. Tesis Fakultas Psikologi Unika Atma Jaya Jakarta.

Soleman, Aminah. 2011. Analisis Beban Kerja Ditinjau Dari Faktor Usia Dengan Pendekatan Recommended Weiht Limit. Jurnal Arika, Vol.05 No.02 
JEMASI Vol.14 No.2, Jul-Des 2018 